1997

\title{
Employer Recruiting and the Gender Composition of Jobs
}

F. Carson Mencken

Idee Winfield

Follow this and additional works at: https://researchrepository.wvu.edu/rri_pubs

Part of the Regional Economics Commons

\section{Digital Commons Citation}

Mencken, F. Carson and Winfield, Idee, "Employer Recruiting and the Gender Composition of Jobs" (1997). Regional Research Institute Publications and Working Papers. 188.

https://researchrepository.wvu.edu/rri_pubs/188 


\section{Employer Recruiting and the Gender Composition of Jobs}

\section{F. Carson Mencken \& Idee Winfield}

To cite this article: F. Carson Mencken \& Idee Winfield (1999) Employer Recruiting and the Gender Composition of Jobs, Sociological Focus, 32:2, 201-220, DOI:

10.1080/00380237.1999.10571135

To link to this article: https://doi.org/10.1080/00380237.1999.10571135

曲 Published online: 19 Nov 2012.

Submit your article to this journal $\pi$

山 Article views: 75

Citing articles: 11 View citing articles 4 


\title{
EMPLOYER RECRUITING AND THE GENDER COMPOSITION OF JOBS*
}

\author{
F. CARSON MENCKEN \\ West Virginia University \\ IDEE WINFIELD \\ College of Charleston
}

\author{
SOCIOLOGICAL FOCUS \\ Vol. 32 No. 2 \\ May 1999
}

\begin{abstract}
In this paper we examine employer recruiting in the external labor market as an intervening mechanism in the process of job gender segregation. We use data from the Metropolitan EmployerWorker Survey to examine the effects of informal and formal recruiting techniques on the gender composition of jobs, and how the characteristics of jobs, organizations, occupations and industries affect the use of formal and informal recruiting. Jobs more frequently recruited through formal techniques, such as advertisements, employ more women. In contrast, jobs more frequently recruited through inforinal techniques, such as business colleagues, employ fewer women. The effects of recruiting, however, are not always straightforward. Smaller establishments more frequently use current employees to recruit than do larger establishments. When smaller establishments use current employees to recruit this has a negative effect on the representation of women in jobs, while in larger establishments the use of current employees increases the representation of women.
\end{abstract}

\section{INTRODUCTION}

$\mathbf{T}$ he negative consequences of job gender segregation are well-documented. Gender segregation places women into a narrower range of jobs that offer limited training, fewer opportunities for advancement, lower wages, less autonomy and limited authority (Bielby and Baron 1984, 1986; Blau 1975; Baron and Newman 1989; DiPrete and Soule 1988; England 1992; England et al. 1988; Jacobs 1989; Reskin and Roos 1990; Roos and Reskin 1992; Rosenfeld 1980, 1983; Singelmann and Mencken 1992; Wolf and Fligstein 1979a, 1979b; Tomaskovic-Devey 1993). Job gender segregation is also implicated in the feminization of poverty and the educational under-attainment of children from female-headed households (England and Browne 1992; Sandefur, McLanahan and Wojtkiewicz 1992).

While the consequences of job gender segregation are understood, there is less agreement about the process of job gender segregation (Hanson and Pratt 1991; Tomaskovic-Devey 1993). Some argue that the primary source of gender segregation is structurally embedded organizational practices that shape who are sought and hired (Acker 1990; Bielby and Baron 1984, 1986; Hacker 1990; Strang and Baron 1990). Others point to social control mechanisms that affect which jobs women and men pursue and how they pursue them (Jacobs 1989; Campbell and Rosenfeld 1985;

* This is a substantially revised version of a paper presented at the annual meetings of the International Sunbelt Network Association, New Orleans, LA. Both authors contributed equally to the paper and are listed in alphabetical order. We would like to thank Karen Campbell and Bill Danaher for helpful comments on a previous draft, and the Regional Research Institute at WVU for technical support. 
Hanson and Pratt 1991). Each of these arguments implicitly addresses one side of job matching processes and how they shape the gender composition of jobs (Granovetter 1981; Campbell 1988; Hanson and Pratt 1991).

Most of the existing studies of job matching and gender segregation examine how women and men search for jobs in external labor markets (Campbell and Rosenfeld 1985; Hanson and Pratt 1991; Marx and Leicht 1992; Braddock and McPartland 1987; Windolf 1986) or how organizational processes structure internal job ladders and promotion opportunities (DiPrete and Soule 1988; Bielby and Baron 1984; Rosenbaum 1984; Strang and Baron 1990; Williams 1992). These studies document the complexity of the processes that generate and maintain job gender segregation.

In this paper, we address one aspect of the process of job gender segregation not previously examined: organizational recruiting in the external labor market. To date, only a few case studies have examined how employer search for new employees in the external labor market affects the gender composition of jobs (see Hanson and Pratt 1991; Marx and Leicht 1992). More often than not, assumptions about organizational recruiting strategies are implied from information about how job searchers find their jobs. This is problematic because how an employer recruits for a job (e.g., through an employment agency or through business associates) may not be consistent with the means by which job searchers find out about the job. Perhaps a friend tells a job searcher about a job posted at an employment agency. When asked how the job was found, the job searcher responds that it was through a friend. The job searcher's account would not be consistent with the manner in which the employer recruited for the job. We overcome this problem by using job-specific recruiting information provided by hiring managers from organizations in a major metropolitan area.

\section{RECRUITING AND THE GENDER SEGREGATION OF JOBS}

\section{WHY RECRUTTING AFFECTS ACCESS TO JOBS}

Employers use a number of formal and informal recruiting techniques when shopping for labor in external labor markets. According to Marsden and Campbell (1990), formal methods of recruiting involve some formal intermediary between the employee and the firm. These include employment agencies, newspaper and trade publications and even signs placed in windows. Informal methods involve the use of social contacts in the labor market, and include the use of current employees, customers and professional colleagues/business associates to recruit for vacancies.

The technique used to recruit for a job vacancy affects how many people, and what people will have access to information about jobs (Windolf 1986; Haulman, Raffa and Rungeling 1987; Rees and Schultz 1970; Corcoran, Datcher and Duncan 1980). Formal recruiting methods, such as advertisements, broadly disseminate information in the labor market. Informal recruiting through employees and business associates makes job information available to a more limited pool of people.

Although scholars agree that recruiting techniques differentially affect the flow of information in the external labor market, they disagree about why recruiting techniques should affect the gender composition of jobs. Three perspectives, social 
network, organizational efficiency and feminist social closure, offer different explanations for how and why recruiting contributes to job gender segregation.

Social network explanations emphasize that informal recruiting limits the employment opportunities of certain groups (primarily women and minorities) because they do not have access to the networks through which many jobs are recruited (Tomaskovic-Devey 1993; Marx and Leicht 1992; Roos and Reskin 1984; Campbell 1988; Campbell and Rosenfeld 1985). Past research shows that men are more likely to have wider ranging networks consisting of colleagues, co-workers and higher status persons, while women are more likely to have kin-centered and local support networks (Hanson and Pratt 1991; Brass 1985; McPherson and Smith-Lovin 1982; Fischer and Oliker 1983; Marsden 1987; Moore 1990; Kanter 1977). Women and men have different network structures because they are placed in different social-structural locations. Men are more likely than women to have higher status social positions in communities, higher status jobs and fewer domestic responsibilities. Women are more likely than men to work in paid jobs with less status and responsibility, to be physically more isolated from people in higher status jobs and have more domestic responsibilities. Campbell (1988) concludes that women's personal networks are not sufficient to be of great use when searching for other employment. More importantly, she concludes that women's networks are not sufficient to gain unsolicited job information, an important phenomenon in other studies of job matching (Hanson and Pratt 1991; Granovetter 1995).

Organizational efficiency theorists maintain that employers recruit informally to maximize the job match (Simon and Warner 1992; Wood 1985; see also Granovetter 1995 for a review of unpublished manuscripts on this topic). According to Stinchcombe (1990), organizations rely heavily upon certification systems to reduce the inherent risk in hiring new employees. Informal recruiting is a type of certification system that can be used to fill jobs that are central to organizational survival. Better information is found in inter-organizational networks, because of normative expectations of trust that govern these relations (Granovetter 1985). Job gender segregation results when women are excluded from jobs because they lack access to the certification system that employers use to fill particular jobs (see also Barron and Bishop 1985; Wanous 1980).

Scholars from a feminist social closure perspective argue, however, that gender differences in organizational and labor market assets (including information networks) are symptomatic of institutionalized patriarchal privilege. Job gender segregation results from formal and informal barriers to skills, knowledge and social networks that protect the status and rewards of the positions held predominantly by men (Reskin and Roos 1990; Roos and Reskin 1984; Tomaskovic-Devey 1993; Anderson and Tomaskovic-Devey 1995; Milkman 1987; Witz 1986). What appears on the surface to be a legitimate, gender-neutral process (the need to recruit informally to maximize the job match) actually serves to institutionalize gender segregation through patriarchal solidarity (Witz 1986) and social homophily (Reskin and Roos 1990; Windolf 1986; Braddock and McPartland 1987). ${ }^{1}$

Even though the three perspectives provide different reasons why recruiting in external labor markets affects the gender composition of jobs, what they share is that informal recruiting has negative consequences for the representation of women in jobs. The corollary to this expectation is that we should also find a positive effect of formal recruitment on the representation of women. First, as mentioned above, formal 
recruiting techniques disseminate job information to a wider audience in the labor market. For example, more people will have access to advertisements than to the informal networks. If women lack access to informal recruiting networks, then they are more likely to find jobs that are recruited for through formal means (Reskin and Roos 1984; Campbell and Rosenfeld 1985; Hanson and Pratt 1991).

Second, formal recruiting techniques may represent the formalization of employment relations within organizations. To the extent that formalization in hiring and recruiting practices translates into fairness in hiring, women will be able to better use their human capital and compete for these jobs (Tomaskovic-Devey 1993; Jacobs 1989). Formal recruiting techniques also better serve organizations that seek diversity in the applicant pool. Marsden and Campbell (1990) report that current employees and others associated with a firm are likely to pass along information to socially similar individuals - what Kanter (1977) refers to as homosocial reproduction. Thus, formal recruitment may be advantageous for compliance with EEOC employment standards, other government policies (e.g., Executive Orders 11246, 11375) or political pressures (e.g., Operation Push) that compel firms to recruit a diversity of applicants (see Bowes 1987; Jenkins 1986; Bloch 1994; Taylor 1979).

\section{WHY GENDER COMPOSITION AFFECTS RECRUITING}

A careful review of explanations for job gender segregation reveals that the gender composition of jobs also shapes employers' decisions to use formal and informal recruiting techniques. Both organizational efficiency and feminist social closure lead us to expect that male-dominated jobs are more frequently recruited through informal techniques.

From an organizational efficiency perspective asset specificity or firm-specific skills shape organizational strategies for filling vacancies (see Williamson 1975; and also Bridges and Villemez 1991). Informal recruiting is an effective method of locating quality applicants to fill skilled jobs. In contrast, formal recruiting is an efficient means of recruiting for jobs that have less asset specificity and more closely represent commodities on the open market (see Rees and Schultz 1970; Barron and Bishop 1985, for a discussion of the spot market/commodity market model of job matching). Employers may be more likely to view workers in jobs in which women predominate, such as clerical and administrative support, as "commodity items" who can be found through relatively standardized formal recruiting techniques. Furthermore, clerical and administrative support jobs comprise a large proportion of the jobs in the economy and there must be a large and steady supply of potential workers. Indeed hiring managers are most likely to cite the quality of the applicant pool as the reason for informal recruiting and a large pool of applicants as the primary advantage of formal recruiting (Mencken and Winfield 1998). Consequently, gender composition affects how jobs are recruited because women are concentrated in jobs with low asset specificity and high labor demand, which is a basis for formal recruiting.

Why jobs held predominantly by women have lower asset specificity compared to jobs held predominantly by men is central to the feminist social closure perspective. In this framework, jobs and the labor process are gendered (Acker 1990; also see Reskin and Padavic 1994, Chapter 7, for a review of this literature). Cultural beliefs about gender and gender differences in power shape the perceived value of job skills 
(England 1992; Steinberg 1990; Reskin 1988), as well as the implementation of technology and the resulting skill level and job requirements (Reskin and Roos 1990; Hacker 1990). In light of the pervasive effects of gender in the organization of work and jobs, decisions about how to recruit both reflect and reproduce the gender composition of jobs (Leidner 1993; Bielby and Baron 1986; Kanter 1977).

\section{RECRUITING AS AN INTERVENING MECHANISM IN THE PROCESS OF JOB GENDER SEGREGATION}

Clearly, job gender composition is a consequence of mechanisms of labor supply and labor demand. The gender composition of jobs results from the educational and career choices that women and men make and the effects of gendered institutions on those choices, as well as a range of overt and covert discriminatory employer practices. Salary, job responsibility, organizational size, industry sector occupation have all been shown to affect the gender composition of jobs (see England and Browne 1992; Kemp 1994; Reskin and Padavic 1994 for extensive reviews). It is beyond the scope of this paper to specify all the mechanisms that contribute to a model explaining job gender composition. Nevertheless, understanding how recruiting contributes to job gender segregation necessitates that we also take into account the job, organization, occupation and industry characteristics that shape how jobs are recruited for and in turn how recruiting affects job gender composition.

We conceptualize recruiting as an intervening mechanism in the processes linking organizations, occupations and jobs to the gender composition of jobs. We must caution that we are not arguing that the relative impact of recruiting is greater than these other supply and demand mechanisms, only that recruiting techniques are a mechanism in the overall process of job gender segregation that needs to be empirically examined rather than assumed.

\section{DATA AND METHODS}

Data used in the analyses come from the Metropolitan Employer-Worker Survey (MEWS), a 1981 survey of 2,713 workers and their employers in the Chicago MSA (Bridges and Villemez 1994). The MEWS study gathered data from a representative sample of workers age 18 or older who worked 20 hours or more per week for someone else. The respondents from the employee interview provided the name of the person within the company responsible for hiring decisions. In the second stage of the study, hiring managers were interviewed about the job in which the sampled employee worked, including the techniques used to recruit for the job, as well as characteristics of the firm and the establishment. These data were supplemented by data provided by Dun and Bradstreet, and other industrial data sources (Villemez and Bridges 1988). Employer data were not obtained for 786 of the sampled workers. ${ }^{2}$

\section{MEASURES OF INFORMAL AND FORMAL RECRUTTING}

We examine the inter-relationship between six recruiting techniques and the gender composition of jobs in the greater Chicago MSA. All recruiting measures are in response to the following question: When seeking applicants from outside (Company name), do you: 1 Often ask your employees for recommendations? (Current 
Employees); 2. Often ask business associates or professional colleagues for names of applicants? (Colleaguea/Associates); 3. Often place advertisements in newspapers, on the radio, or other mass circulation? (Advertise); 4. Often use signs outside on your premises? (Signs); 5. Often notify employment agencies? (Agencies); 6. Often rely upon applicants walking in or presenting themselves? (Walk-ins). We classify colleagues and current employees as informal recruiting, since they involve the use of social contacts to disseminate job information. The others are classified as formal. ${ }^{3}$

Hiring managers who responded "yes" to a question about a recruiting technique were then asked: "How many of your employees presently working as (job) have been recruited in this way? Would you say none (1), a few (2), some (3), most (4), or all (5)." A "no" response to the first question was assigned to the "none" category. The recruiting measures are ordinal scales of recruiting preference for each of the six techniques used to recruit for a job category.

The questions about recruiting preferences were asked for jobs recruited in the external labor market. Consequently, 600 observations were removed from the analyses because they were filled exclusively from within the establishment.4

\section{GENDER COMPOSITION OF JOBS}

Ideally, we would like to have information that links a specific recruiting event with a specific hiring outcome. Our experience is that establishments are extremely reluctant to provide this information because it may uncover institutionalized discriminatory practices that would then have to be dealt with. Instead we use two indirect indicators of the outcome of typical recruiting methods.

The first indicator is the gender composition of jobs. It is measured as the proportion of women employed in the Census six-digit occupation/industry categories in the Chicago MSA. Data from the PUMS-D for the Chicago MSA were used to calculate the proportion of women in jobs and then merged by six-digit occupation/industry code with the MEWS data. Tomaskovic-Devey (1993, p. 175) points out that most previous general population studies measure the gender composition of occupations rather than jobs and thus miss the substantial variation in gender composition among jobs within occupations. Much, but not all, of that variation occurs across firms in different industries (Bielby and Baron 1986, 1984; Blau 1975; Peterson and Morgan 1995; Reskin and Roos 1990). By using the gender composition for occupations within industries within the Chicago MSA rather than the entire U.S., the measure has more validity as a measure of job gender composition.

The MEWS data also include the gender of the individual respondent in the employee file. We include this as a second indicator of the outcome of recruiting and compare it with the measure of job gender composition in order to address legitimate concerns about how closely our measure of job gender composition represents an actual hiring decision in an establishment. Nevertheless, it is important to remember that unmeasured variations in gender composition across establishments require cautious interpretation. 


\section{CONTROL VARIABLES}

The analyses control for a number of job, organization, occupation and industry characteristics shown in other studies to affect the gender composition of jobs (see Tomaskovic-Devey 1993; Reskin and Padavic 1994; Jacobs 1995 for recent reviews). We control for occupational status (professional, executive/managerial, other whitecollar and blue-collar), starting salary of the job, whether the job is covered by a union contract, time needed to learn the job, how long the employer expects an employee to stay in the job, whether the job is part of an internal labor market, establishment size, government agency status and core/periphery sector. ${ }^{5}$ The operationalization of these variables is found in Appendix A.

\section{ANALYTIC STRATEGY}

Our approach to examining the effects of informal and formal recruiting on job gender composition is threefold. First, we estimate a regression model to examine the effects of each of the recruiting techniques, net of the control variables. The measure of gender composition is a limited dependent variable, with a range from 0 to 1.00 . We use a logit transformation of the form: Proportion Women $=\ln (p /(1-p))$, where $p=$ proportion women employed in each job category and estimate the effects of recruiting variables on the log odds of the likelihood of women being employed in the job category. The coefficients represent a general linear trend. Second, we replicated this analysis with a logistic regression model that predicts the gender of the employee occupying that job $(1=$ men $)$. Third, we treated the recruiting measures as dependent variables and estimated a cumulative logit model that estimated the effects of job gender composition on the ordinal likelihood of using the technique to recruit for a vacancy, net of the effects of other organization, industry and job characteristics. ${ }^{6}$

\section{RESULTS}

\section{EFFECTS OF RECRUTTING ON THE GENDER COMPOSTTION OF JOBS}

The first step of the analysis examines the net effects of each method of formal and informal recruiting on job gender composition. We find limited support for the hypothesis that formal recruiting increases the representation of women (see Table 1). Of the four techniques of formal recruiting, only advertisements significantly increase the representation of women in jobs. For every unit increase in the frequency of recruiting through advertisements, the proportion of women increases by nine percent.

The lack of significant net effects for employment agencies and signs may be due to their limited use. Compared to advertising, employers are much less likely to use employment agencies and signs to recruit new employees. Only 18 percent of all jobs in these data were ever recruited through employment agencies and 10 percent of jobs were ever recruited through the use of signs. Given some of the problems with recruiting through employment agencies, such as high service fees and employee pirating (Wanous 1980), it is not surprising that many employers do not use the method. In addition, the recruiting questions do not distinguish between public and 


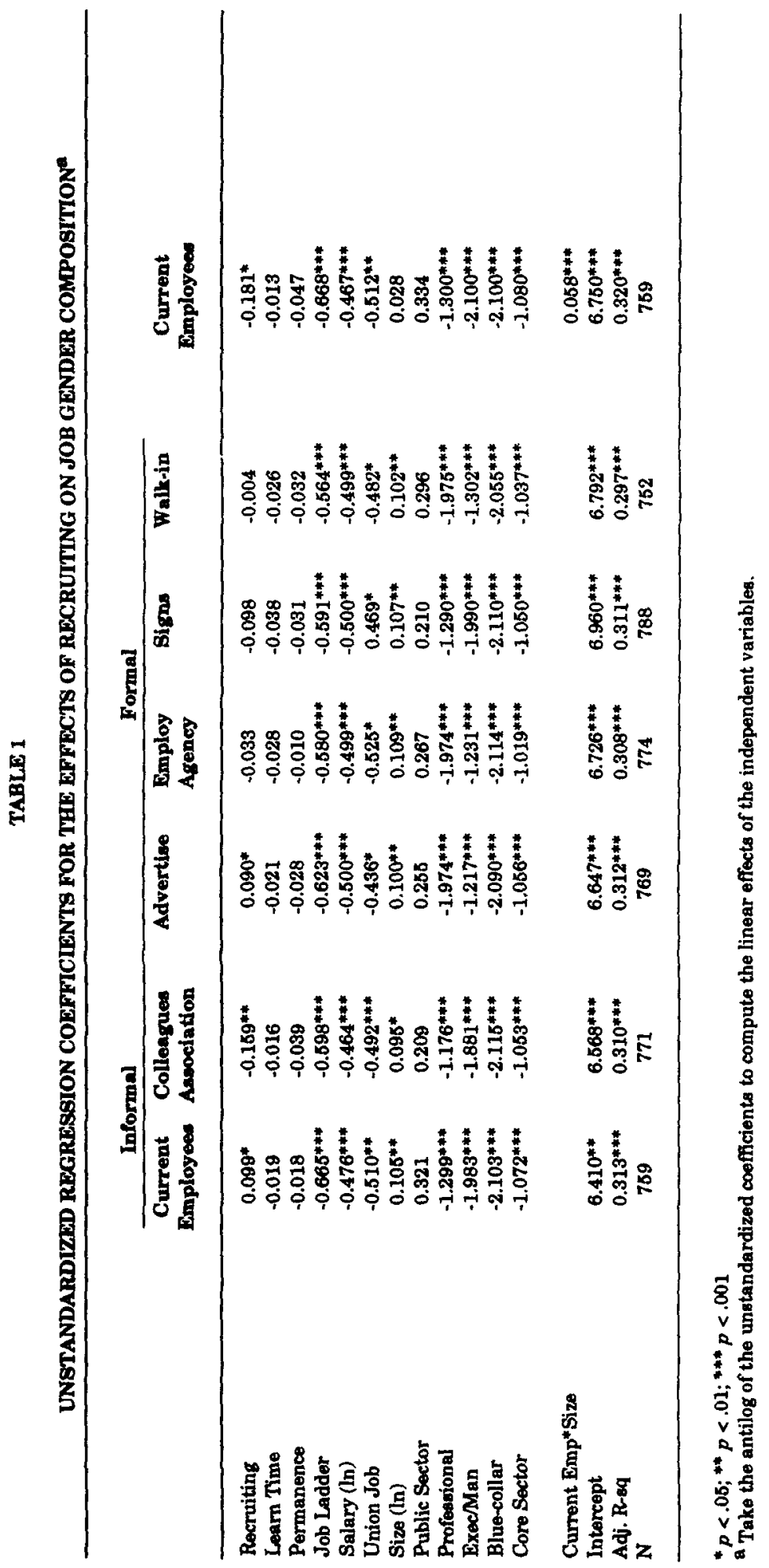


private employment agencies, which is an important distinction documented in past research (Wanous 1980; Rees and Schultz 1970).

The hypothesis for informal recruiting also receives partial support. The analysis shows that recruiting through colleagues and associates has a negative effect on the representation of women. For every unit increase in the frequency of recruiting through colleagues and associates, the proportion of women decreases by 16 percent.

The model for the use of current employees does not support the argument that informal methods of recruiting have a negative effect on the representation of women. The more frequently current employees are used to recruit, the greater the representation of women. The representation of women in a job increases ten percent with each unit increase in the frequency of recruiting through current employees. One reason why may be that the causal relationship between recruiting and job gender composition is mis-specified as one-sided. Explanations of job gender segregation focus on the "old boy" network and how it is used to recruit men into male-dominated positions. But informal recruiting can also produce job gender segregation if employees in jobs held predominantly by women are called upon to recruit for vacancies. Given gender differences in network structure (see Moore 1990; Hanson and Pratt 1991), it is likely that women would recruit other women, thereby reproducing job gender segregation (Kanter 1977; Marsden and Campbell 1990).

Table 2 presents the logistic regression analysis, which uses the same recruiting and control variables to predict the gender of a person who occupies a given job within the establishment. With one exception, the effects of the recruiting variables are similar in magnitude and direction to those reported for gender composition in Table 1. Each unit increase in the frequency with which employers use informal recruiting through colleagues and associates increases the probability that the person employed is a man by 13 percent. In contrast, each unit increase in the frequency with which employers use current employees to recruit increases the probability that the person employed is a woman by 17 percent. Recruiting through advertisements, however, does not predict the gender of the job-holder.

The purpose of the logistic regression analysis is to help assess how much confidence we should place in the findings for the measure of job gender composition. Assuming that the gender of the respondent in the employee file is likely to be typical of persons in that job in that establishment, the similarity in the net effects of the recruiting variables allows us to cautiously conclude that informal recruiting plays a role in job gender segregation. Similar net effects of the control variables on the two indicators of recruiting outcomes help to further convince us that job gender composition measures meaningful variation among establishments. Men are more likely than women to be employed in jobs that are unionized, have promotion potential and higher salaries, are in the "core" sector of the economy and are professional, executive/managerial or blue-collar. These same variables have negative effects on the proportion of women in jobs. Furthermore, the effects of the control variables on job gender composition are consistent with those reported by Tomaskovic-Devey (1993), who uses a more direct measure of the gender composition of jobs in firms. 


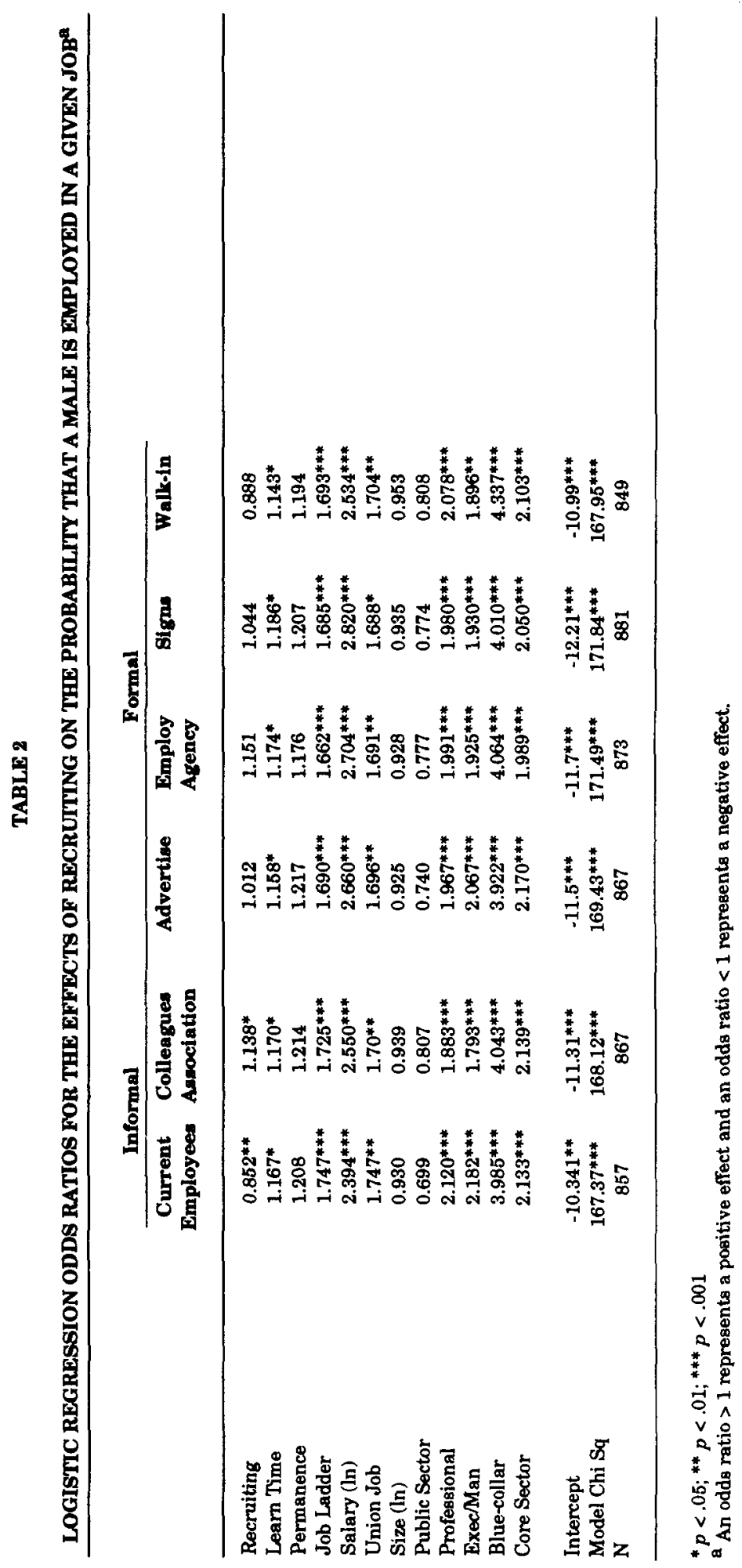


EFFECTS OF JOB GENDER COMPOSITION ON THE USE OF FORMAL AND INFORMAL RECRUTTING

Although we cannot estimate the reciprocal relationship between recruiting and gender composition, the cumulative logit analysis (Table 3) does provide some insights about the other side of the relationship. Here we examine the net effects of job gender composition on how frequently employers use formal and informal methods to recruit for jobs. In addition, examining the net effects of the characteristics of jobs, organization, occupation and industry serves to further specify how recruiting contributes to the processes generating and maintaining job gender segregation.

The net effect of gender composition on formal recruiting mirrors the effects of formal recruiting on the gender composition of jobs. As the representation of women increases, employers report more frequent use of advertisements to fill jobs. For each 1 percent increase in the proportion of women in jobs, the proportional odds of recruiting more frequently through advertisements increase 8.7 percent. We again find no relationship between job gender composition and the use of employment agencies, signs or walk-ins.

We found that job gender segregation accounts for the differential use of advertising among occupations. Prior to including job gender composition, the proportional odds of employers using advertisements is significantly lower for professional jobs compared to clerical and service occupations. The effect disappears once the gender composition of jobs is included in the model. In addition to gender composition, employers more frequently use advertisements to recruit for jobs in larger establishments, in the private sector and that are not covered by union contracts.

The effect of gender composition on informal recruiting also mirrors the effects of informal recruiting on the gender composition of jobs. The representation of women has a negative effect on the use of colleagues and associates but a positive effect on the use of current employees. For every one percent increase in the proportion of women in jobs, the proportional odds of using colleagues and associates to recruit decrease by eight percent. For current employees, however, the proportional odds of use increase by 9.4 percent.

Among informal recruiting techniques, colleagues and associates are more frequently used to recruit for jobs that are executive/managerial, provide higher starting salaries and are located in smaller establishments. Current employees are more frequently used to recruit for jobs in smaller establishments, in the private sector and for jobs that are part of internal labor markets.

In light of the finding that the use of current employees has a positive effect on the representation of women and that employers more frequently use current employees to recruit for jobs in organizations that generally have been found to have more gender segregation (Table 1), we decided to explore the conditional effect of current employees on job gender composition. The last column in Table 1 tests for the interaction of establishment size and frequency of recruiting through current employees on the proportion of women in a job category. The significant interaction indicates that the effect of current employees on the proportion of women in a job category is conditional on the size of the establishment. As the frequency of recruiting through current employees increases there is a negative effect on the proportion of women in jobs in very small establishments, and a positive effect on the proportion of 


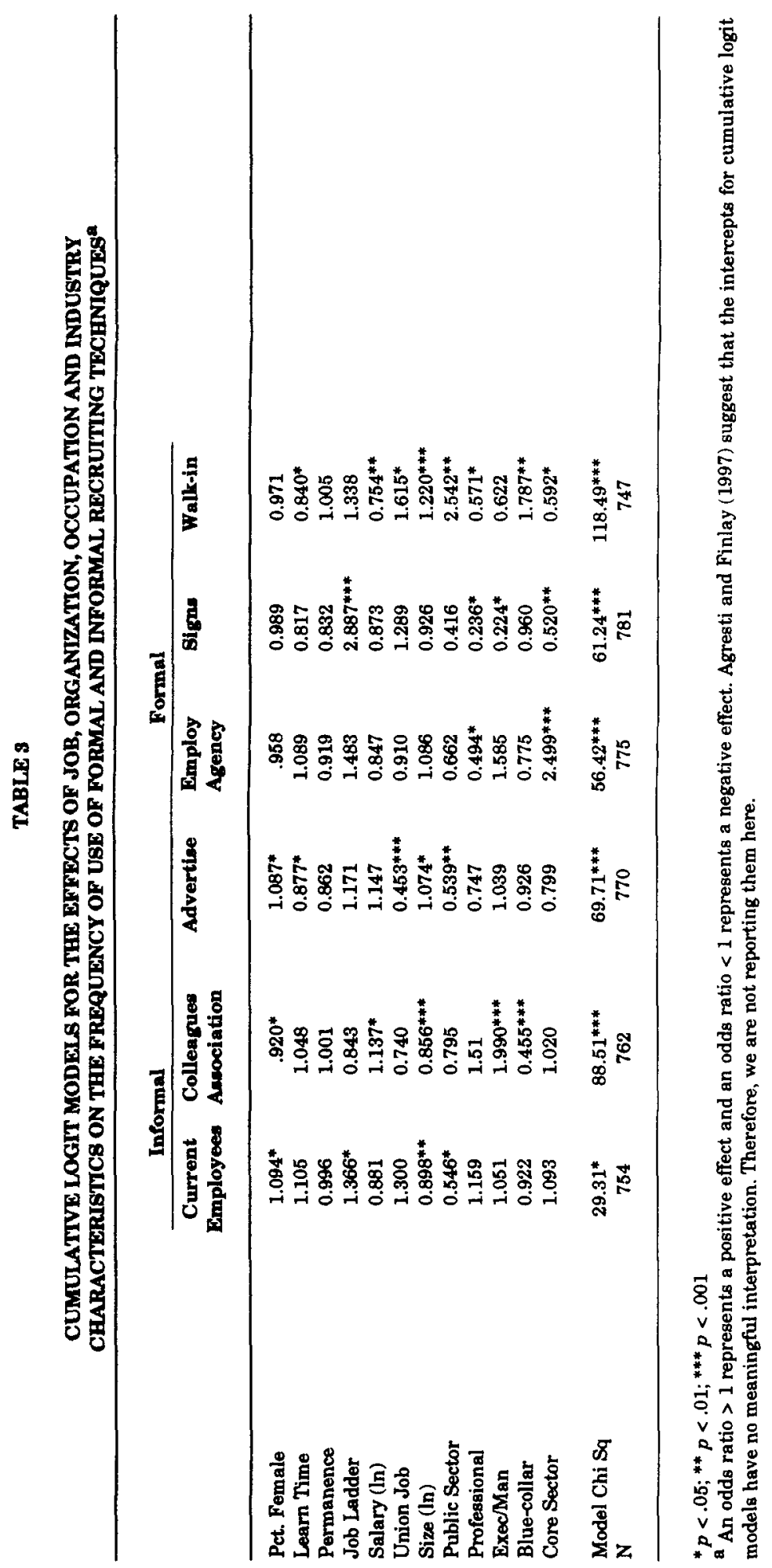


women in jobs in larger establishments. Thus, smaller establishments more frequently use current employees to recruit in the external labor market, but the more frequently smaller establishments recruit through current employees, the smaller the representation of women in those jobs. Conversely, larger establishments less frequently use current employees to recruit, but when larger establishments do frequently recruit through current employees it is for jobs that have a larger representation of women. ${ }^{7}$

Given the interaction effect of recruitment through current employees and establishment size, we also estimated the effects of job, organization, occupation and industry characteristics on the use of current employees to recruit for large establishments sizes (over 100 , over 250 , over 500 ). The analysis shows that in larger establishments current employees are more frequently used to recruit employees for jobs that are more permanent (where the employee would be expected to stay in the job for a long time) and that are part of an internal labor market (these results are available upon request). Others have argued that once hired, employees in these types of jobs are difficult to remove (Bridges and Villemez 1991; Boswell 1988; Stinchcombe 1990). Thus, we maintain that when larger establishments recruit through current employees, it is done to recruit women for jobs from which they are not easily removed. Perhaps employers are compelled to recruit in this manner to carefully select the women hired into these positions. By using current employees to recruit, employers invoke a norm of trust. Current employees will be reluctant to recruit "unsuitable" candidates into these jobs (Granovetter 1995; Simon and Warner 1992; Wood 1985), thereby avoiding the risks referred to in statistical discrimination explanations (see Reskin and Padavic 1994; Tomaskovic-Devey 1993; Jacobs 1995 for reviews). Moreover, normative expectations of trust give employers a certain degree of control over workers. A worker recruited into an organization by a family member or friend is likely to conform to organizational norms and expectations. To "buck" authority would also damage the reputation of the person who referred the individual for the job (Granovetter and Tilly 1988; Jenkins et al. 1983; Fevre 1989; Windolf 1986; Wood 1985; Grieco 1987). Therefore, employers may maintain control by bringing women into the organization (in particular for positions that have promotion potential and/or for which a long-term employee is sought) by using current employees to recruit (and socialize) women into these jobs.

\section{DISCUSSION}

Persistent job segregation of women and men cannot be explained as simply a matter of choice on the part of workers or gender discrimination on the part of employers. Increasingly scholars recognize that the complex process of job matching must be integrated into the study of job gender segregation (see Hanson and Pratt 1991). Although recruiting is recognized as having an important role in segregation processes (Roos and Reskin 1992, 1984; Rosenfeld 1980; Reskin 1988), there is a paucity of empirical study of employer recruiting in external labor markets (see Granovetter 1995 for review). Most of the accepted wisdom about the effects of recruiting on job gender composition are based on studies of employee job search. In this paper we empirically examine how employer recruiting affects the gender 
composition of jobs. We do so with data collected from establishments in a major metropolitan area.

The results of our analyses generally support expectations about the effects of recruiting on the gender composition of jobs, and also further specify how job, organization, occupation and industry characteristics shape the gender composition of jobs through recruiting. The analysis shows that, all else being equal, jobs that are more frequently recruited through advertisements employ a greater proportion of women. In contrast, jobs that are more frequently recruited through colleagues and associates employ lower proportions of women.

These results support past conclusions about recruitment drawn by Campbell and Rosenfeld (1985) with data on how people found jobs. They concluded that women were more likely to find employment in white-collar occupations that were recruited through formal methods (advertisements, employment agencies). Our analysis shows some support for this possibility. Hanson and Pratt (1991) show that women are more likely to find jobs through advertisements and direct application. Our analysis shows that when advertisements are used to recruit, these jobs employ a larger proportion of women. Hanson and Pratt (1991) also show that women are less likely to find jobs through contacts than are men, and our results show that when colleagues and associates at other firms are used to recruit, there are relatively fewer women in these jobs.

In addition, Hanson and Pratt (1991) argue that men are more likely to find jobs through employment agencies than women. Our results show no effect for recruitment through employment agencies net of controls for job, organization, occupation and industry characteristics. Moreover, our data indicate that relatively few jobs are recruited for through employment agencies ( 18 percent in this sample).

The most interesting finding concerns the conditional effects of recruiting through current employees. Recruiting through current employees has a positive effect on the proportion of women in jobs in larger establishments but a negative effect on the proportion of women in jobs in smaller establishments. Furthermore, larger establishments less frequently recruit through current employees compared to smaller establishments. Thus, job gender segregation is not simply a result of which techniques are used, but of how organizations use them. Much more attention needs to be given to studying the selection of recruiting techniques and how they sustain or if change the gender composition of jobs within organizations.

Future studies also need to address the possibility that the relationship between recruiting and job gender composition is spurious. Some will contend that informal recruiting is negatively associated with the gender composition of jobs because of choice or human capital reasons. If there is an under-supply of qualified women for the jobs that are typically recruited for through colleagues and associates, or women do not aspire to these types of jobs to the same extent that men do, some may argue that the relationship between recruitment and job gender composition has more to do with self-selection than recruiting. In our analysis we include several characteristics of jobs (starting salary, permanence of employment, whether or not the job was on an internal job ladder, time needed to learn the job) that capture self-selection via aspirations or human capital. As in past studies, we find that these characteristics of jobs do have independent effects on job gender composition. However, net of these 
effects, there are subtle but significant effects of recruiting on the gender composition of jobs.

While this study empirically addresses an important question about the relationship between recruiting and the gender composition of jobs, we also caution that more definitive conclusions await better measures of job gender composition and recruiting. In this study we measure the gender composition of jobs with the proportion of women in six-digit Census occupation/industry categories for the Chicago MSA. We included a second indicator of the outcome of recruiting in order to address legitimate concerns about how closely our measure of job gender composition represents an actual hiring decision in an establishment. While this is clearly better than relying upon gender composition of occupations, which others have done (Hanson and Pratt 1991; Marx and Leicht 1992), we recognize that there is unmeasured variation in gender composition of jobs within occupation/industry categories. Job gender composition measured at the task level within firms, such as that collected by Tomaskovic-Devey (1993) would provide an even stronger test of the effect of recruiting techniques on job gender composition.

A second limitation concerns the measurement of recruiting. The questions about recruiting in the MEWS data were asked about the job, not how the individual employee was recruited to the job. While we can still make a link between recruiting and job gender composition based on this line of questioning, data that connects recruiting to a specific individual would allow us to examine how recruiting techniques may be differentially used to recruit women and men into the same job category. In addition, the recruiting techniques asked about in the MEWS data were not an exhaustive inventory of all methods of recruiting. For example, no distinction was made between public and private employment agencies, an important distinction in past research (Wanous 1980). Additionally, no questions were asked about recruiting through headhunter firms, which some suggest is a hybrid of formal and informal recruiting.

The generalizability of our findings are limited by time and place of data collection. The Chicago MSA may be more or less representative of other metropolitan areas, but that is an empirical question without a clear answer. Other studies with data from other labor markets are needed. In addition, the MEWS data were collected in 1981 . Therefore, these data inform us about how recruiting affected the gender composition of jobs in 1980.

Despite these limitations of the data, this study provides empirical information that addresses an important question. It is the first study to our knowledge that examines the effects of recruiting practices on job gender composition within a major labor market with data collected from employers. Although the data were collected in 1980 , they provide a base-line that future studies (when data are collected) can use to assess change. Our analysis estimates the effects of recruiting on job gender composition at an historical moment when occupational segregation had rapidly decreased (Cotter et al. 1995) and the processes of job segregation and ghettoization within occupations were emerging (Reskin and Roos 1990; Jacobsen 1994; Tanner and Cockerill 1996).

Clearly more complete data are needed to more fully examine the complex relationship between how people are matched to jobs and structured social inequality in our society. In this paper we empirically show that how employers recruit in 
external labor markets is one important mechanism in the process of job gender segregation.

F. Carson Mencken is an assistant professor of Sociology at West Virginia University. His research interests include the social dimensions of labor markets and a research agenda which focuses on the determinants of economic growth and community well-being. He has publications in print or forthcoming in Sociological Focus, The Sociological Quarterly, Growth and Change, and Rural Sociology.

Idee Winfield is an Associate Professor of Sociology at the College of Charleston. Her principal research interest is organizational determinants of gender employment inequality. In addition to the study of organizational recruiting, she is collaborating with Von Bakanic on a study of historical changes in the visibility of women sociologists in the American Journal of Sociology.

\section{NOTES}

1. Similar arguments are made about race and recruiting by Neckerman and Kirschenman (1991).

2. We examined the distribution of the missing cases relative to the distribution of 1980 occupation/ industry categories in the Chicago SMSA. We found that professional and executive managerial jobs were slightly over-represented in our missing observations.

3. The use of applicants who walk in is not a true formal method of recruiting because there is no formal intermediary between the employee and the firm (Marsden and Campbell 1990). It is even less a method of informal recruiting, since no social contact is formally used to disseminate information about the job. It may be best to think of walk-ins as passive recruiting. Rather than exclude walk-ins from the analysis of formal and informal recruiting, we include it for the purposes of comparison.

4. Ideally, we would like to compare how internal and external recruiting affect the gender composition of jobs. To date, much more is understood about job matching in internal labor markets than in external labor markets. Furthermore, existing studies of internal labor markets, internal recruiting and promotion, suggest that there are distinctive internal organizational processes shaping the gender composition of jobs (Bowes 1987; Collinson et al. 1990; Gans 1987; DiPrete and Soule 1988; Williams 1992; Bielby and Baron 1984). A more complete understanding of how internal and external recruiting contribute to job gender segregation awaits better data (see Granovetter 1995).

5. Approximately 120 cases did not report starting salary of the job. We recaptured these missing cases by substituting the mean starting salary for the particular occupation by industry code for that position.

6. We considered both a structural equation model, and a two-stage least squares model to better account for the reciprocal relationship between recruiting and gender job composition. However, we do not have adequate indicators for each dimension to estimate a LISREL model. A minimum of three indicators are recommended for a dimension to be locally identified. We have only two indicators of most dimensions, and one indicator of several others. The alternative, two stage least squares is also inappropriate because the recruiting measures are ordinal measures. Furthermore, factor analygis of the measures of formal and informal recruiting did not reveal well-defined factor structures (the highest coefficient of reliability was only .40). Mencken and Winfield (1998) makes clear why constructing indices from these measures is not appropriate.

7. We also find that current emplayees interact with establishment size when predicting the gender of an employee working in that position. The probability that current employees are used to recruit women increases by 4 percent for each 1 percent increase in establishment size. Results available upon request. 


\section{REFERENCES}

Acker, Joan. 1990. "Hierarchies, Jobs, Bodies: A Theory of Gendered Organizations." Gender \& Society 4:139158.

Agresti, Alan and Barbara Finlay. 1997. Statistical Methods for the Social Sciences (3rd Ed.). Upper Saddle River, NJ: Prentice Hall.

Anderson, Cynthia and Donald Tomaskovic-Devey, 1995. "Patriarchal Pressures: An Exploration of Organizational Processes that Exacerbate and Erode Gender Earnings Inequality." Work and Occupations 22:328-356.

Baron, James N. and Andrew Newman. 1989. "Pay the Man: Effect of Demographic Composition on Prescribed Wage Rates in the California Civil Service." Pp. 107-130 in Pay Equity: Empirical Inquiries, edited by Robert Michael, Heidi Hartmann and Brigid O'Farrell. Washington, DC: National Academy Press.

Barron, John M. and John Bishop. 1985. “Extensive Search, Intensive Search and Hiring Costs: New Evidence on Employer Hiring Activity." Economic Inquiry 23:363-382.

Bielby, William T. and James N. Baron. 1986. "Men and Women at Work: Sex Segregation and Statistical Discrimination." American Journal of Sociology 91:759-799.

—_. 1984. “A Woman's Place Is with Other Women: Sex Segregation within Organizations." Pp. 27-55 in Sex Segregation In The Workplace: Trends, Explanations, Remedies, edited by Barbara F. Reskin. Washington, DC: National Academy Press.

Blau, Francine. 1975. "Sex Segregation of Workers by Enterprise." Pp. 257-275 in Labor Market Segmentation, edited by R. Edwards, M. Reich and D. Gordon. Lexington, MA: D.C. Heath.

Bloch, Farrell E. 1994. Antidiscrimination Law and Minority Employment: Recruitment Practices and Regulatory Constraint. Chicago: University of Chicago Press.

Boswell, Terry. 1988. "Control of Work and Worker Control: A Conflict Theory of the Governance of Transaction Costs in Work Relations. ${ }^{p}$ Research in Social Stratification and Mobility 7:135-162.

Bowes, Lee. 1987. No One Need Apply: Getting and Keeping the Best Workers. Cambridge, MA: Harvard Business School Press.

Braddock, Jomills H. and James M. McPartland. 1987. "How Minorities Come to Be Excluded from Equal Employment Opportunities." Journal of Social Issues 43:5-39.

Brass, Daniel J. 1985. “Men's and Women's Networks: A Study of Interaction Patterns and Influence in an Organization." Academy of Management Journal 28:327-43.

Bridges, William P. and Wayne J. Villemez. 1991. "Employment Relations and the Labor Market: Integrating Institutional and Market Perspectives. ${ }^{n}$ American Sociological Review 56:748-764.

1994. The Employment Relationship: Causes and Consequences of Modern Personnel Administration. New York: Plenum.

Campbell, Karen E. 1988. "Gender Differences in Job-Related Networks." Work and Occupations 15:179-200.

Campbell, Karen E. and Rachel Rosenfeld. 1985. “Job Search and Job Mobility: Sex and Race Differences." Pp. 147-174 in Research in the Sociology of Work, edited by Richard L. Simpson and Ida Harper Simpson. JAI Press.

Collinson, David L., David Knights and Margaret Collinson. 1990. Managing to Discriminate. London: Routledge.

Corcoran, Mary, Linda Datcher and Greg J. Duncan. 1980. "Information Networks in Labor Markets." Pp. 1-37 in Five Thousand American Families: Patterns of Economic Progress, Vol. VIII, edited by Greg J. Duncan and James N. Morgan. Ann Arbor, MI: University of Michigan, Institute for Social Research.

Cotter, David A. Joann M. Defiore, Joann M. Hermsen, Brenda Marstellar Kowalweski and Reeve Vanneman. 1995. "Occupational Gender Desegregation in the 1980s." Work and Occupations 22:3-21.

DiPrete, Thomas A. and Whitman T. Soule. 1988. "Gender and Promotion in Segmented Job Ladder Systems." American Sociological Review 53:26-40.

England, Paula. 1992. Comparable Worth: Theories and Evidence. New York: Aldine de Gruyter.

England, Paula and Irene Browne. 1992. “Trends in Women's Economic Status." Sociological Perspectives 35:17-51.

England, Paula, George Farkas, Barbara Kilbourne and Thomas Dou. 1988. "Explaining Occupational Sex Segregation and Wages: Findings from a Model with Fixed Effects." American Sociological Review 53:544-658.

Fevre, Ralph. 1989. "Informal Practices, Flexible Firms and Private Labour Markets." Sociology 23:91-109.

Fischer, Claude and Stacey J. Oliker. 1983. "A Research Note on Friendship, Gender and the Life Cycle." Social Forces 62:124-133.

Gans, Janet. 1987. "Men's Career Advantages in Nursing: The Principle of the Peter." Current Research on Occupations and Professions 4:181-198.

Granovetter, Mark S. 1981. "Toward a Sociological Theory of Income Differences." Pp. 11-47 in Sociological Perspectives on Labor Markets, edited by Ivar Berg. New York: Academic Press.

1985. "Economic Action and Social Structure: The Problem of Embeddedness." American Journal of Sociology 91:481-510. 
1995. Getting a Job. 2nd ed. Cambridge, MA: Harvard University Press.

Granovetter, Mark S. and Charles Tilly. 1988. "Inequality and Labor Processes." Pp. 175-221 in Handbook of Sociology, edited by N. Smelser. Newbury Park, CA: Sage.

Grieco, Margaret. 1987. Keeping It in the Family: Social Networks and Employment Chance. London: Tavistock.

Hacker, Sally. 1990. Doing It the Hard Way. Boston: Unwin Hyman.

Hanson, Susan and Geraldine Pratt. 1991. "Job Search and the Occupational Segregation of Women." Annals of the Association of American Geographers 81:229-253.

Haulman, Clyde A., Frederick A. Raffa and Brian Rungeling. 1987. "Assessing the Labor Market Intermediary Role of the Job Service." Growth and Change 16:66-71.

Jacobs, Jerry. 1989. Revolving Doors: Sex Segregation and Women's Careers. Stanford, CA: Stanford University Press.

__ 1995. "Introduction." Pp. 1-20 in Gender Inequality at Work, edited by Jerry Jacobs. Thousand Oaks, CA: Sage.

Jenkins, Richard. 1986. Racism and Recruitment: Managers, Organisations and Equal Opportunity in the Labour Market. New York: Cambridge University Press.

Jenkins, Richard, Alan Bryman, Janet Ford, Teresa Keil and Alan Beardeworth. 1983. "Information in the Labour Market: The Impact of Recession." Sociology 17:260-267.

Kanter, Rosabeth Moss. 1977. Men and Women of the Corporation. New York: Basic Books.

Kemp, Alice Abel. 1994. Women's Work, Degraded and Devalued. Engelwood Cliffs, NJ: Prentice Hall.

Leidner, Robin. 1993. Fast Food, Fast Talk: Service Work and the Routinization of Everyday Life. Berkeley: University of California Press.

Marsden, Peter V. 1987. "Core Discusiion Networks of Americans." American Sociological Review 52:122-131.

Marsden, Peter V. and Karen C. Campbell. 1990. "Recruitment and Selection Processes: The Organizational Side of Job Searches." Pp. 59-79 in Social Mobility and Social Structure, edited by Ronald Breiger. Cambridge, MA: Cambridge University Press.

Marx, Jonathan and Kevin Leicht. 1992. "Formality of Recruitment to 229 Jobs: Variations by Race, Sex and Job Characteristics." Sociology and Social Research 76:190-96.

McPherson, Miller and Lynn Smith-Lovin. 1982. "Women and Weak Ties: Differences by Sex and Size of Voluntary Organizations." American Journal of Sociology 87:883-904.

Mencken, F. Carson and Idee C. Winfield. 1998. "In Search of the 'Right Stuff: The Advantages and Disadvantages of Formal and Informal Recruiting Practices in External Labor Markets." The American Journal of Economics and Sociology 57:135-154.

Milkman, Ruth. 1987. Gender at Work. Urbana, IL: University of Illinois Press.

Moore, Gwen. 1990. "Structural Determinants of Men's and Women's Personal Networks." American Sociological Review 55: 726-735.

Neckerman, Kathryn M. and Joleen Kirschenman. 1991. ${ }^{\alpha}$ Hiring Strategies, Racial Bias and Inner City Workers." Social Problems 38:433-447.

Peterson, Trond and Laurie A. Morgan. 1995. "Separate and Unequal: Occupation-Establishment Sex Segregation and the Gender Wage Gap." American Journal of Sociology 101:329-365.

Rees, Albert and George P. Schultz. 1970. Workers and Wages in the Urban Labor Market. Chicago: University of Chicago Press.

Reskin, Barbara. 1988. "Bringing the Men Back In: Sex Differentiation and the Devaluation of Women's Work." Gender \& Society 2:58-81.

Reskin, Barbara and Irene Padavic. 1994. Women and Men at Work. Thousand Oaks, CA: Pine Forge Press.

Reskin, Barbara F. and Patricia A. Roos. 1990. Job Queues and Gender Queues. Philadelphia: Temple University Press.

Roos, Patricia A. and Barbara F. Reskin. 1984. "Institutional Factors Contributing to Sex Segregation in the Workplace." Pp 235-260 in Sex Segregation in the Workplace: Trends, Explanations and Remedies, edited by Barbara F. Reskin. National Academy Press.

- 1992. "Occupational Desegregation in the 1970s: Integration and Economic Equity?" Sociological Perspectives 35:69-91.

Rosenbaum, James E. 1984. Career Mobility In a Corporate Hierarchy. New York: Academic Press.

Rosenfeld, Rachel. 1980. "Race and Sex Differences in Career Dymamics." American Sociological Review 45:583-609.

- 1983. "Sex Segregation and Sectors: An Analysis of Gender Differences in Returns to Employer Changes." American Sociological Review 48:637-655.

Rosenfeld, Rachel and Kenneth Spenner. 1995. "Occupational Sex Segregation and Women's Early Career Job Shift." Pp. 231-258 in Gender Inequality at Work, edited by Jerry Jacobs. Thousand Oaks, CA: Sage.

Sandefur, Gary D., Sara McLanahan and Roger A. Wojtkiewicz. 1992. "The Effects of Parental Marital Status during Adolescence on High School Graduation." Social Forces 71:103-122.

Simon, Curtis J. and John T. Warner. 1992. "Matchmaker, Matchmaker: The Effect of Old Boy Networks on Job Match Quality, Earnings and Tenure.” Journal of Labor Economics 10:306-329. 
Singelmann, Joschim and F. Carson Mencken. 1992. "Job Autonomy in Advanced Industrialized Countries." Social Science Quarterly 73:829-843.

Steinberg, Ronnie J. 1990 "The Social Construction of Skill." Work and Occupations 17:449-82.

Stinchcombe, Arthur L. 1990. Information and Organizations. Berkeley, CA: University of California Press.

Strang, David and James N. Baron. 1990. "Categorical Imperatives: The Structure of Job Titles in California State Agencies." American Sociological Review 55:479-495.

Tanner, Julian and Rhonda Cockerill. 1996. "Gender, Social Change and the Professions: The Case of Pharmacy." Sociological Forum 11: 643-660.

Taylor, Patricia A. 1979. "Income Inequality in the Federal Civilian Government." American Sociological Review 55:479-495.

Tolbert, Charles, Patrick Horan and E. M. Beck. 1980. "The Structure of Economic Segmentation." American Sociological Review 52: 195-210.

Tomaskovic-Devey, Donald. 1993. Gender and Racial Inequality at Work: The Sources and Consequences of Job Segregation. Ithica, NY: ILR Press.

Villemez, Wayne J. and William T. Bridges. 1988. "When Bigger Is Better: Differences in the Individual-Effect of Firm and Establishment Size." American Sociological Review 53:237-255.

Wanous, John P. 1980. Organizational Entry: Recruitment, Selection and Socialization of Newcomers. Reading, MA: Addison-Wesley.

Williams, Christine L. 1992. "The Glass Escalator: Hidden Advantages for Men in the Female Professions." Social Problems 39:253-267.

Williamson, Oliver. 1975. Markets and Hierarchies: Analysis and Antitrust Implications. New York: Free Press.

Windolf, Paul. 1986. "Recruitment, Selection and Internal Labor Markets in Britain and Germany." Organizational Studies 7:235-254.

Witz, Anne. 1986. "Patriarchy and the Labour Market: Occupational Control Strategies and the Medical Division of Labour." Pp. 14-35 in Gender and the Labor Process, edited by David Knights and Hugh Wilmott. Hampshire, England: Gower.

Wolf, Wendy C. and Neil D. Fligstein. 1979a. "Sex and Authority in the Workplace: The Causee of Sexual Inequality." American Sociological Review 44:235-252.

1979b. "Sexual Stratification: Differences in Power in the Work Setting." Social Forces 58:94-107.

Wood, Stephen. 1985. "Recruitment Systems and the Recession." British Journal of Industrial Relations 23:103-120.

\section{APPENDIX A}

\section{MEASUREMENT OF JOB, OCCUPATION, ORGANIZATION AND INDUSTRY CHARACTERISTICS}

\section{Learn Time}

Based on the following question: From the time that they begin, how much time does a typical new employee need to learn the job of (title) in your establishment? 1) minutes, 2) hours, 3) days, 4) weeks, 5) months, 6) years?

\section{Permanence}

From the following question: When looking for a quality in a worker, is it 4) extremely important, 3) somewhat important, 2) not very important, or 1) not at all important that the candidate is likely to stay with the organization for a long time, that is, are permanent?

\section{Avg Starting Sal.(ln)}

What is the average starting salary for this position in your company? (Salaries reported in annual, monthly, weekly and hourly rates. All values converted to 52 weeks, 40 hours a week).

Size (ln)

This measure is operationalized as the number of full and part-time employees in that establishment.

\section{Public Sector}

Binary variable $(0,1)$ from the following question: Is this establishment part of federal, state or local government? Yes $=1$ 


\section{APPENDIX A (Continued)}

Job Ladder

Binary variable $(0,1)$ from employer reports that this job is part of a regular series of positions by which people move to a higher level.

\section{Union Job}

To be eligible for this job, is it necessary for the applicant to be a member of a union? $1=Y e s, 0=$ No

\section{Occ Status}

3 Binary measures: Professional, Executive/Managerial, Blue-Collar. Other white collar is suppressed.

\section{Core Sector}

Whether the job is in the Core/periphery Economic Sectors defined according to Tolbert et al. (1980). 